Journal of Fish Diseases

February 2008, Volume 31, Issue 2 : Pages 153-157

http://dx.doi.org/10.1111/j.1365-2761.2007.00865.x

(c) 2008 Blackwell Publishing, Inc.

The definitive version is available at www.blackwell-synergy.com
Archimer, archive institutionnelle de l'Ifremer http://www.ifremer.fr/docelec/

\title{
In situ hybridization detection of initial infective stages of Marteilia refringens (Paramyxea) in its host Mytilus galloprovincialis
}

\author{
N. Carrasco ${ }^{1,4}$, I. Arzul' ${ }^{2}$, F. C. J. Berthe ${ }^{3}$ and M. D. Furones ${ }^{1,4, *}$
}

${ }^{1}$ IRTA, St Carles de la Rapita, Spain

2 IFREMER, Genetic and Pathology Laboratory, La Tremblade, France

${ }^{3}$ Canada Research Chair in Aquatic Animal Health, Department of Pathology and Microbiology of Atlantic

Veterinary College, University of Prince Edward Island, Charlottetown, PE, Canada

${ }^{4}$ Aquaculture Reference Network of Catalonia, RAq, Spain

*: Corresponding author : Dr M D Furones, IRTA, St Carles de la Rapita, Tarragona 43540, Spain, e-mail address : dolors.furones@irta.es

\section{Short Communication}

Keywords: connective tissue, early stages, gills, in situ hybridization, Marteilia refringens, mussel. 
Marteilia refringens is a protistan parasite of the phylum Paramyxea, which affects economically important bivalve species in Europe, such as the European flat oyster Ostrea edulis, and the mussels, Mytilus edulis and M. galloprovincialis (Lopez-Flores, de la Herran, Garrido-Ramos, Navas, RuizRejon \& Ruiz-Rejon 2004). Infection with Marteilia refringens is listed as a notifiable disease by the World Organization for Animal Health (OIE) because of the detrimental impact of the parasite on infected mollusc cultures. However, the life cycle of the parasite is still unclear although recent research points towards a presumed zooplanktonic intermediary host (Audemard, Le Roux, Barnaud, Collins, Sautour, Sauriau, De Montaudouin, Coustau, Combes \& Berthe 2002; Berthe, Le Roux, Adlard \& Figueras 2004; Carrasco, Arzul, Furones, Chollet, Robert, Joly \& Berthe 2005; Carrasco, Lopez-Flores, Alcaraz, Furones, Berthe \& Arzul in press). Marteilia refringens is usually found in the digestive gland of flat oysters and mussels. Young stages of $M$. refringens have been described in the epithelia of stomach and primary digestive tubules, whereas more mature stages of the parasite can be found in the epithelium of the digestive gland tubules (Grizel, Comps, Bonami, Cousserans, Duthoit \& Pennec 1974; Berthe et al. 2004) wheresporulation takes place. However, a few studies have reported the presence of young plasmodial stages of the parasite in gill tissues of $O$. edulis (Comps 1970; Grizel et al. 1974) and M. galloprovincialis (Robledo \& Figueras 1995). This location was considered unusual and not the normal location of the parasite(Comps 1970; Grizel et al. 1974; Robledo \& Figueras 1995; Berthe et al. 2004). Development of molecular detection techniques for Marteilia, such as in situ hybridization (ISH) (Le Roux, Audemard, Barnaud \& Berthe 1999), may be very useful to improve the understanding of the parasite cycle within its host, and to observe early infections which are not easy to detect by routine histological observation. For example, ISH was used to describe the early development of M. sydneyi in its host Saccostrea glomerata (Kleeman, Adlard \& Lester 2002). This report presents a preliminary study using ISH for the detection of all parasitic stages of $M$. refringens occurring throughout the year, paying special attention to initial infective and early stages of the parasite with the aim of improving the understanding of the life cycle of $\mathrm{M}$. refringens and its transmission.

The delta of the River Ebro is located in N.W. Spain. Sediments of the River Ebro form and shape this delta, which is comprised of two semi-enclosed bays: Fangar Bay to the north and Alfacs Bay to the south. Both are exploited for mollusc aquaculture and fisheries. The mussel samples used in this study were obtained from experimental ropes, on a commercial raft stocked with Alfacs natural spat collected during spring 2004. Sixty mussels were randomly collected each month during the study period between October 2004 and October 2005. Half of the body of each mussel was fixed in 10\% formalin in filtered sea water for $24-48 \mathrm{~h}$, and afterwards preserved in $70 \%$ ethanol for histological studies, in order to detect the presence of early stages of Marteilia. Samples were dehydrated and embedded in paraffin wax. Paraffin blocks were cut at $3 \mu \mathrm{m}$ and stained with haematoxylin and eosin (H\&E). Slides were studied under light microscopy at x40.

In situ hybridization analyses were carried out to detect the early stages of the parasite in mussel tissues. Each month, three mussels showing early stages of $M$. refringens by histology, or with suspected unknown stages, were tested by ISH. A total of 36 individuals were examined. ISH was performed as described by Le Roux et al. (1999). Paraffin sections of $7 \mu \mathrm{m}$ thickness were placed on aminoalkylsilane coated slides (Silane-Prep Slides; Sigma, St Louis, MO, USA) deparaffinated and then treated with proteinase $\mathrm{K}\left(100 \mathrm{gg} \mathrm{mL}^{-1}\right)$ in TE buffer (50 mM Tris, $10 \mathrm{mM}$ EDTA) at $37^{\circ} \mathrm{C}$ for 20 $\mathrm{min}$. Slides were dehydrated by immersion in an ethanol series and air-dried. Sections were incubated with $50 \mu \mathrm{L}$ of hybridization buffer (4x SSC, $50 \%$ formamide, 1x Denhardt's solution, $250 \mathrm{\mu g} \mathrm{mL}^{-1}$ yeast tRNA, dextran sulphate $10 \%$ ) containing $10 \mathrm{ng}$ of the digoxigenin-labelled probe specific for Marteilia species (Smart2). Sections were placed on a heating block at $95{ }^{\circ} \mathrm{C}$ for $5 \mathrm{~min}$, cooled on ice for $1 \mathrm{~min}$ before $4 \mathrm{~h}$ hybridization at $42{ }^{\circ} \mathrm{C}$ in a humid chamber. Sections were washed twice for 5 min in $2 \mathrm{x}$ SSC at room temperature, and once for $10 \mathrm{~min}$ in $0.4 \mathrm{x} \mathrm{SSC}$ at $42{ }^{\circ} \mathrm{C}$. The detection step was performed according to the manufacturer's instructions (Dig Nucleic Acid Detection Kit; BoehringerManheim, Manheim, Germany). Counter staining was carried out with Bismarck brown yellow and rinsing in ethanol, followed by application of cover slips using an aqueous mounting medium. Heavily infected mussel tissues were used as positive controls in each batch, while uninfected mussel tissues were used as negative controls.

Marteilia refringens was observed by histology in the 12 samples of 60 animals collected monthly with prevalences ranging from $3.34 \%(2 / 60)$ in January to $26.67 \%(16 / 60)$ in July. Plasmodial early stages could be detected throughout the year, mostly in association with more mature stages of the parasite. These early stages were observed in the epithelia of the mantle, stomach and primary digestive 
tubules. Mature stages of the parasite were observed in the epithelium of the secondary digestive tubules.

In situ hybridization showed strongly labeled stages of different morphology in the digestive gland of most individuals. However, in one sample collected in July, numerous labelled cells of the parasite were also observed in the epithelium of the gills (Fig. 1) and the mantle (Fig. 2), as well as in the connective tissue of the mantle and digestive gland (Fig. 3). Parasites located in the epithelia of the gills and mantle epithelium appeared in clusters along the basal membrane of the epithelium. Parasites located in the connective tissues usually appeared isolated. Different stages of the parasite were also observed in the digestive tissues of the same individual (Fig. 4). No haemocytic host response was observed around the parasites. Sequential paraffin sections of the same parasitized individual were stained by H\&E for histological observations and although some parasites could be observed in the connective tissue, they were difficult to detect. Some of the examined mussels (11) showed very faint labelling, even if the positive control and the remainder of the slides from the same batch showed strong labelling. Initial stages of paramyxean development are not easily detectable by routine histological observation, especially when there is no host reaction or tissue disruption around the parasite. For this reason, ISH may be very useful to elucidate the parasite cycle within its host. Marteilia sydneyi had never been detected in palps and gills of Saccostrea glomerata until ISH was used (Kleeman et al. 2002). The presence of early developmental stages of Marteilioides chugmuensis was also described in Crassostrea gigas gills, palps and mantle epithelia after ISH andelectron microscopy (Itoh, Komiyama, Ueki \& Ogawa 2004). In the present ISH study, only one mussel showed parasites in the epithelium of the gills and mantle, and in the connective tissues of the mantle and digestive gland. Nevertheless, such occurrences are probably underestimated because the number of animals tested by ISH was low (36) and some individuals showed only very faint labelling (11), which did not allow detailed analysis of the material. The mussel with parasites in the gill epithelium was collected in July, which is during the transmission and infection period of the parasite in Mytilus galloprovincialis (Robledo \& Figueras 1995; N. Carrasco, unpublished data). For this reason, and considering the similarities with the results of Kleeman et al. (2002), the epithelium of the gills may be considered as a potential route of entry for $M$. refringens. However, $M$. refringens appears to penetrate its host through most epithelia, including gills, mantle and also stomach and primary digestive tubules. Parasites located in gill and mantle epithelia could move, through systemic circulation and/or by migration through tissues (supported here by the occurrence of labeled parasites in the connective tissues), to the digestive tissues to complete their development by sporogenesis. Detection of the initial infective stages of $M$. refringens in the epithelia of the gills and mantle epithelia of $M$. galloprovincialis suggests that infection results from a "free-floating" parasite stage, acquired through the bivalve filter-feeding process, which comes into contact with gills and palps, as proposed by Kleeman et al. (2002). This hypothesis implies that the parasite is released from the intermediate host to its surrounding environment as the free-floating form. Additional studies of the initial stages of development of $M$. refringens using electron microscopy are thus required to further understand the parasite life cycle.

\section{Acknowledgements}

This work was carried out with funding from an INIA pre-doctoral grant provided by the Spanish Government and INIA project RTA04-023 (co-ordinated by Dr Montse Ramon). We would like to thank especially Gloria Macia and Olga Bellot for technical support and Dr Chris Rodgers for his interesting advice. We would also like to thank Dr Laurence Elandaloussi, Dr Karl Andre and Dr Ana Roque for their advice with molecular tools, as well as Dr Jorge Diogene for coordinating the field sampling. In addition, we would like to thank Captain Josep $\mathrm{M}^{\mathrm{a}}$ Reverté for taking samples.

\section{References}

Audemard C., Le Roux F., Barnaud A., Collins C., Sautour B., Sauriau P.G., De Montaudouin X., Coustau C., Combes C. \& Berthe F. (2002) Needle in a haystack: involvement of the copepoda 
Paracartia grani in the life-cycle of the oyster pathogen Marteilia refringens. Parasitology 124, 315323.

Berthe F., Le Roux F., Adlard R. \& Figueras A. (2004) Marteiliosisin molluscs: a review. Aquatic Living Resources 17, 433- 448.

Carrasco N., Arzul I., Furones D., Chollet B., Robert M., Joly J.P. \& Berthe F. (2005) Comparative experimental infection of Marteilia spp. from mussels and oysters in the copepod Paracartia grani. 12th EAFP International Conference on Diseases of Fish and Shellfish, Copenhagen, Denmark, $p$. 206.

Carrasco N., Lopez-Flores I., Alcaraz M., Furones M.D., Berthe F. \& Arzul I. (2007) Dynamics of the parasite Marteilia refringens (Paramyxea) in Mytilus galloprovincialis and zooplankton populations in Alfacs Bay (Catalonia, Spain). Parasitology 134, 1541-1550.

Comps M. (1970) Observations sur les causes d'une mortalité abnormal des huîtres plates dans le bassin de Marennes. Revue Travaux Institut Pêches Maritimes 34, 317-326.

Grizel H., Comps M., Bonami J.R., Cousserans F., Duthoit J.L. \& Pennec M. (1974) Epizooty of the common oyster Ostrea edulis. Part 1 . Study of the agent of digestive gland disease in Ostrea edulis (Linne). Sciences Peche 240, 1-30.

Itoh N., Komiyama H., Ueki N. \& Ogawa K. (2004) Early developmental stages of a protozoan parasite, Marteilioides chungmuensis (Paramyxea), the causative agent of the ovary enlargement disease in the Pacific oyster Crassostrea gigas. International Journal for Parasitology 34, 1129-1135.

Kleeman S.N., Adlard R.D. \& Lester R.J.G. (2002) Detection of the initial infective stages of the protozoan parasite Marteilia sydneyi in Saccostrea glomerata and their development through to sporogenesis. International Journal for Parasitology 32, 767- 784.

Le Roux F., Audemard C., Barnaud A. \& Berthe F. (1999) DNA probes as potential tools for the detection of Marteilia refringens. Marine Biotechnology 1, 588-597.

Lopez-Flores I., de la Herran R., Garrido-Ramos M., Navas J., Ruiz-Rejon C. \& Ruiz-Rejon M. (2004) The molecular diagnosis of Marteilia refringens and differentiation between Marteilia strains infecting oysters and mussels based on the rDNA IGS sequence. Parasitology 129, 411-419.

Robledo J.A.F. \& Figueras A. (1995) The effects of culture-site, depth, season, and stock source on the prevalence of Marteilia refringens in cultured mussels (Mytilus galloprovincialis LMK.) from Galicia, Spain. Journal of Parasitology 81, 354-363.

Received: 13 March 2007

Revision received: 8 May 2007

Accepted: 9 May 2007 


\section{Figures}

(a)
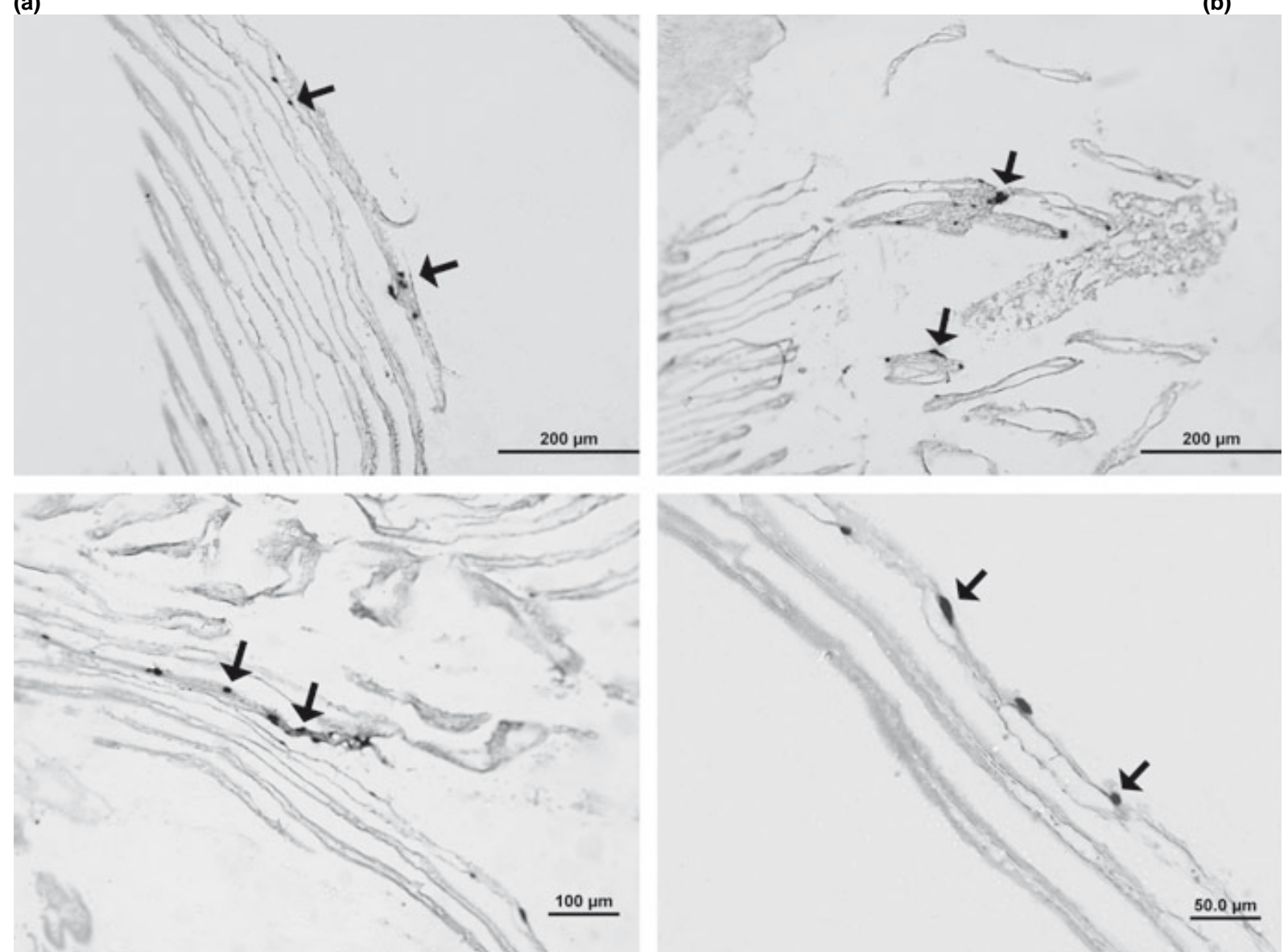

(c)

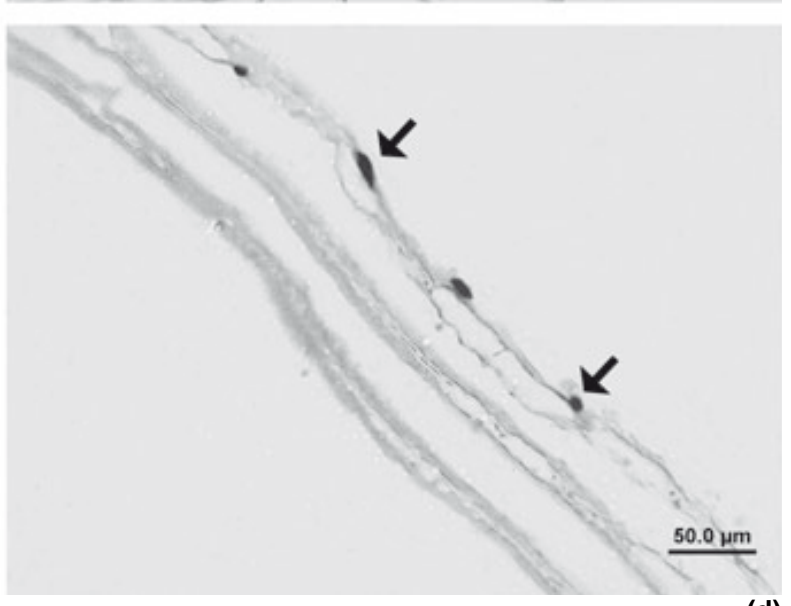

(d)

Figure 1 (a-d) Detection of early stages of Marteilia refringens (arrows) in gill epithelium of Mytilus galloprovincialis by in situ hybridization using the digoxigenin-labelled Smart2 DNA probe.

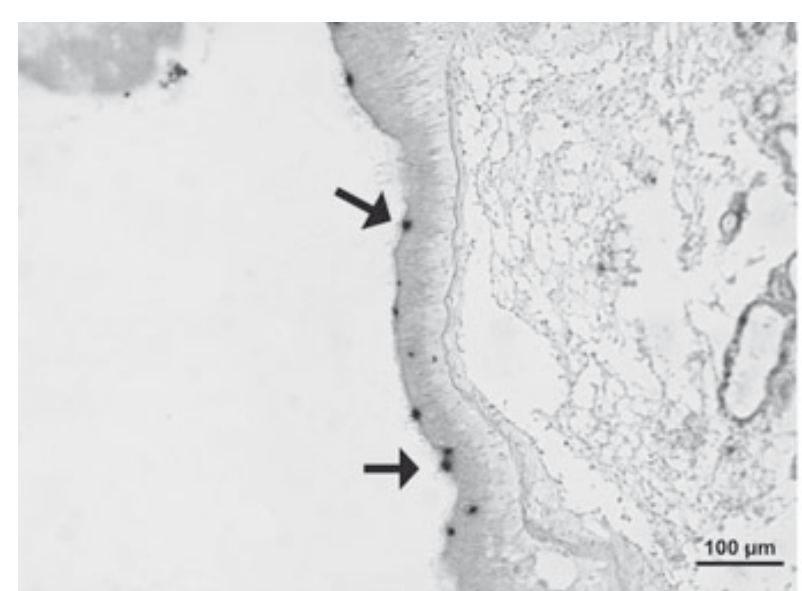

(a)

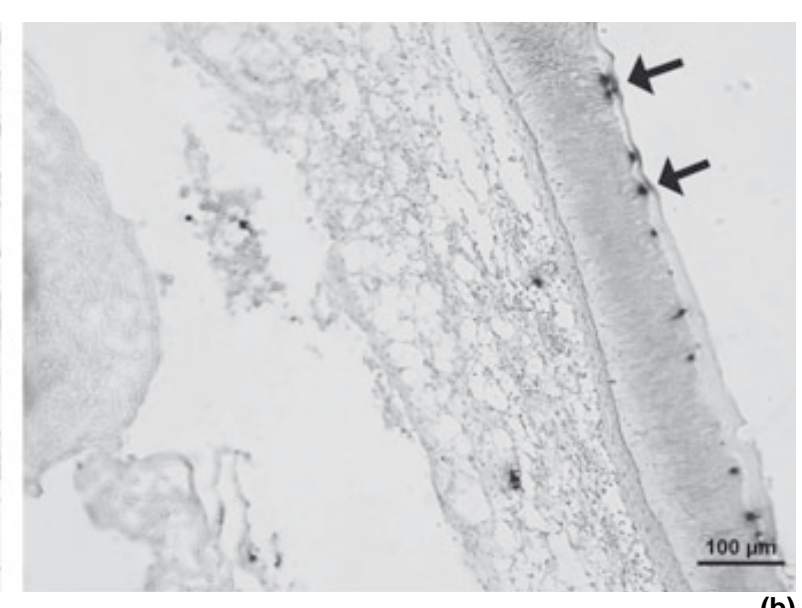

(b)

Figure $2(a, b)$ Detection of early stages of Marteilia refringens (arrows) in mantle epithelium of Mytilus galloprovincialis by in situ hybridization using the digoxigenin-labelled Smart2 DNA probe. 


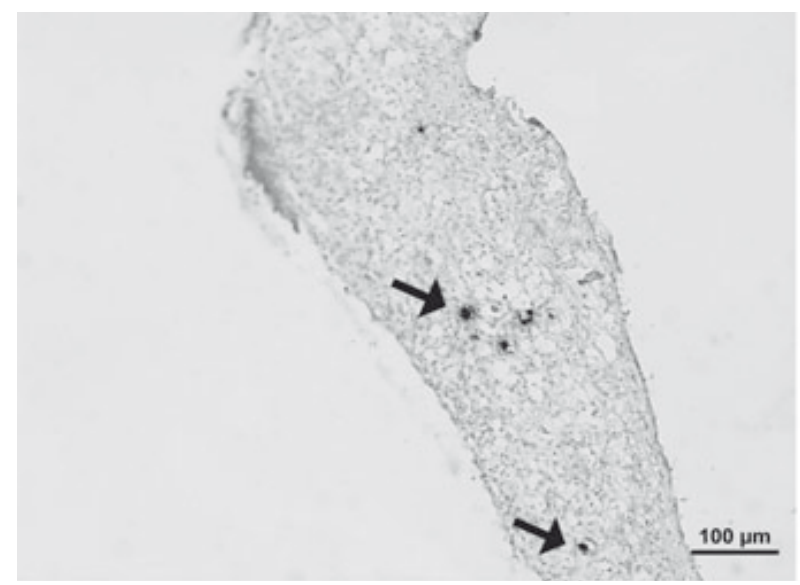

(a)

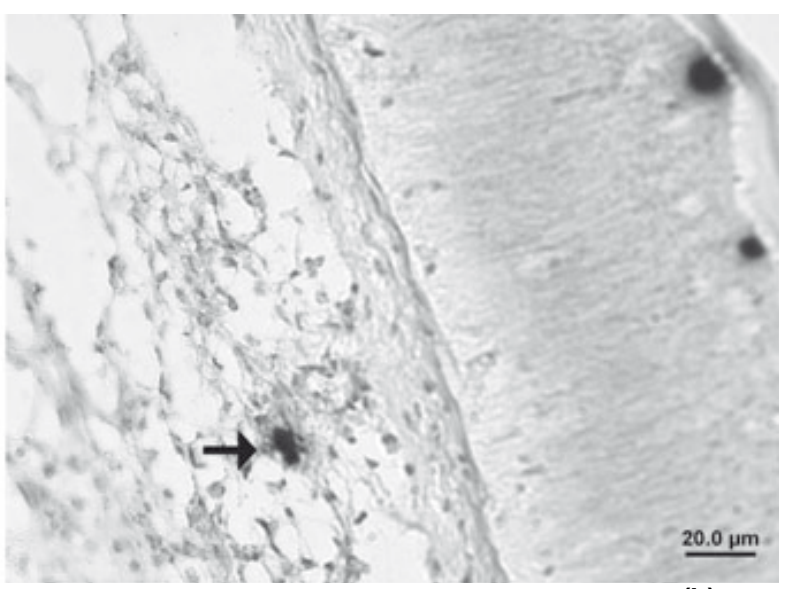

(b)

Figure $3(a, b)$ Detection of early stages of Marteilia refringens (arrows) in mantle connective tissue of Mytilus galloprovincialis by in situ hybridization using the digoxigenin-labelled Smart2 DNA probe.

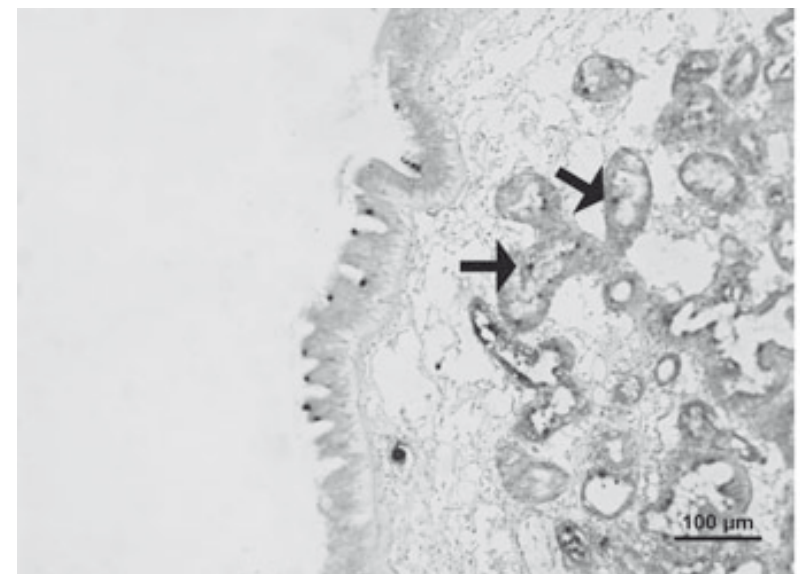

(a)

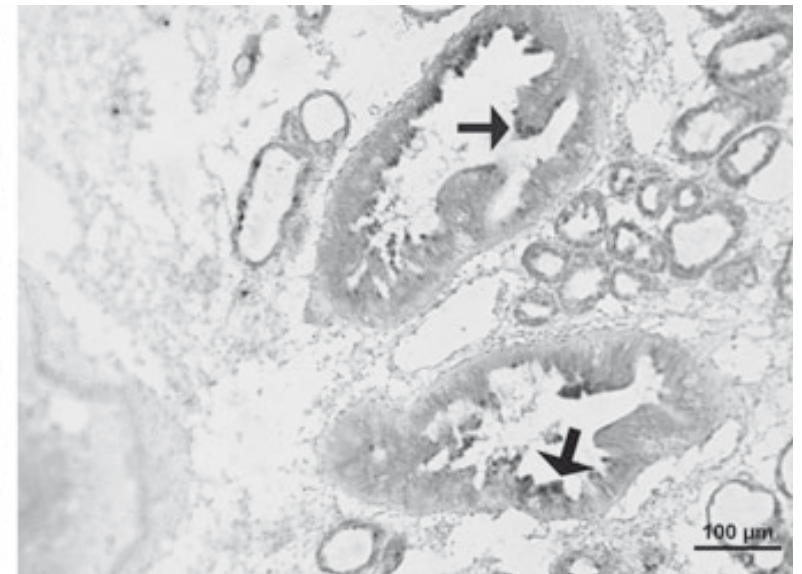

(b)

Figure 4 Detection of different stages of Marteilia refringens in digestive tissues of Mytilus galloprovincialis by in situ hybridization using the digoxigenin-labelled Smart2 DNA probe. (a) Labelled M. refringens cells in secondary digestive tubules (arrows), the parasite can also be observed in epithelium and connective tissue; (b) labelled M. refringens cells in primary digestive tubules (arrows). 